\title{
CONSUMER BEHAVIORAL INTENTIONS TOWARDS MOBILE PAYMENT SERVICES: AN EMPIRICAL ANALYSIS IN PAKISTAN
}

\section{NAMJERE PONAŠANJA POTROŠAČA PREMA USLUGAMA MOBILNOGA PLAĆANJA: EMPIRIJSKO ISTRAŽIVANJE U PAKISTANU}

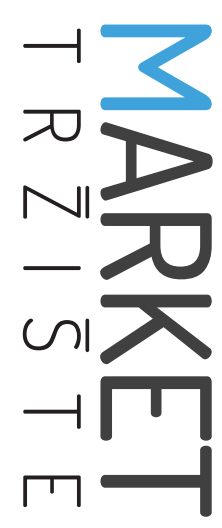

Market-Tržište

Vol. 29, No. 2, 2017, pp. 161-176

UDK 366.1:004.7:654.03(549)

DOl http://dx.doi.org/10.22598/mt/2017.29.2.161

Preliminary communication

\author{
Wajeeha Aslama, Marija Ham ${ }^{\text {, Imtiaz Arif }}$ \\ a) IQRA University, Abid Town, Gulshan e lqbal, Karachi, PAKISTAN, wajeeha_aslam_87@live.com \\ b) Faculty of Economics, University of Osijek, Gajev trg 7, Osijek, CROATIA, mham@efos.hr \\ c) IQRA University, Abid Town, Gulshan e Iqbal, Karachi, PAKISTAN, arif.i@iuk.edu.pk
}

\begin{abstract}
Purpose - This research aims to investigate the behavior of consumers towards the implementation of mobile payment services, factors that can affect their attitudes towards this behavior, and how these attitudes transform into intentions.

Methodology - A survey instrument was developed using items developed in similar studies. In total, 335 usable responses were used to do a series of statistical tests aimed at confirming the reliability and validity of the instrument. Hypotheses were tested using structural equation modeling.

Findings and Implications - Our results showed that perceived compatibility, perceived usefulness, and subjective norm are significant predictors of consumer attitude towards the use of mobile payment services, whereas the impact of perceived security and perceived ease on attitude is insignificant. Finally, attitude towards mobile payment services have a significant impact on intention to use mobile payment services. This research contributes to the development of the technology acceptance model (TAM) in general, as well as in the context of mobile payment services. It tests TAM's explanatory ability and suggests new variables as model extensions.
\end{abstract}

\section{Sažetak}

Svrha - Ovo istraživanje ima za cilj istražiti ponašanje potrošača prema implementaciji usluga mobilnoga plaćanja, čimbenike koji mogu utjecati na stav prema tom ponašanju te kako se taj stav pretvara u namjeru ponašanja.

Metodološki pristup - Mjerni je instrument oblikovan korištenjem čestica razvijenih za potrebe sličnih istraživanja. Ukupno je valjano ispunjeno 335 upitnika, a odgovori ispitanika podvrgnuti su nizu statističkih testova kako bi se potvrdila pouzdanost i valjanost mjernog instrumenta. Hipoteze su testirane primjenom modeliranja strukturnih jednadžbi.

Rezultati i implikacije - Rezultati pokazuju da su percipirana kompatibilnost, percipirana korisnost i subjektivne norme značajne prethodnice stava prema korištenju usluga mobilnoga plaćanja. Znači, percipirana sigurnost i percipirana jednostavnost korištenja nemaju značajan utjecaj na stav o uslugama mobilnog plaćanja. Konačno, stav prema uslugama mobilnoga plaćanja ima značajan utjecaj na namjeru korištenja ovih usluga. Istraživanje doprinosi razvoju Technology acceptance model (TAM) teorije općenito i u kontekstu usluga mobilnog plaćanja. Ispituje se istraživačka sposobnost ove teorije te predlažu nove varijable kao proširenja modela. 
Limitations - The fact that the sample includes respondents from only one country (Pakistan) could be considered the main limitation of this study. A cross-cultural study would likely lead to important knowledge since cultural context has proved to be important in previous research on intentions. Also, the sample used here comprises mostly young and educated people.

Originality - The present research study empirically tests the significance of newly suggested TAM extensions (subjective norm and perceived security) and provides a complete and tested measurement instrument as a basis for future research.

Keywords - intention to use mobile payment services, perceived ease of use, perceived compatibility, perceived security, perceived usefulness, subjective norm
Ograničenja - Uzorak ispitanika iz jedne zemlje može se smatrati glavnim ograničenjem istraživanja. Kroskulturno istraživanje dovelo bi do važnih spoznaja jer se kulturni kontekst pokazao važnim u prethodnim istraživanjima namjera. Isto tako, korišteni uzorak uključuje pretežno mlade i obrazovane ispitanike.

Doprinos - Istraživanje empirijski ispituje značaj predloženih novih proširenja TAM modela (subjektivnu normu i percipiranu sigurnost) te pruža cjelovit i testiran mjerni instrument kao osnovu za buduća istraživanja.

Ključne riječi - namjera korištenja usluga mobilnog plaćanja, percipirana jednostavnost korištenja, percipirana kompatibilnost, percipirana sigurnost, percipirana korisnost, subjektivna norma 


\section{INTRODUCTION}

Today, information technology advancement has transformed the world into a global village. In recent years, the use of mobile phones and mobile technology has increased manifold. This overwhelming increase in the adoption of mobile phones is due to the numerous useful applications and services available on mobile phones which bring convenience to the mobile phone users (Arif, Aslam \& Ali, 2016). The convenience that mobile phones offer is unmatchable by any other technology; hence, they have become an integral part of daily life (Hwang, Shiau \& Jan, 2007).

Among many mobile services, mobile payment service has always been a topic of interest for business practitioners, financial intermediaries, and researchers. Rampton (2016) notes that $37 \%$ of mobile phone users used a mobile phone payment system in 2015, anticipating that more than 4.8 billion mobile phone users would use a mobile phone payment system by the end of 2016. Schierz, Schilke and Wirtz (2010) claim that mobile phone technology advancement is trending towards mobile payment service. Bakker (2016) has mentioned that a delay in the implementation of the necessary infrastructure and consumer disinterest are preventing mobile payment system from achieving mainstream adoption. Moreover, he estimated that in-store mobile payment volume would reach USD 75 billion in the United States by the end of 2016, and USD 503 billion by the end of 2020. Mobile payment systems have also played a prominent role in the developing world (Smith, Anderson \& Rainie, 2016). In Pakistan, many companies offer mobile payment services (e.g. Easy paisa by Telenor, Upaisa by Ufone, Mobicash by Mobilink, and Timepey by Zong), and almost all banks offer branchless banking facilities. According to Arif and others (2016), since the availability of $3 \mathrm{G}$ and $4 \mathrm{G}$ services in Pakistan, the demand for smartphones has risen tremendously. Moreover, Pakistan is witnessing an Internet boom with over 30 million broadband and 27 million mobile data users, and 3G/4G services have pushed mobile payment transactions up by five percent to PKR 26 billion in 2015-16 (Ibrahim, 2016).

All of the above data show that mobile payment services are becoming important for consumers as well as for the economy and also indicate the existence of some difficulty in introducing these technologies at a faster rate. Therefore, there is a need to examine which factors bring about positive attitudes of consumers towards mobile payment services. Previous studies have provided the limited understanding of the key drivers towards increased use of mobile payment services (Schierz et al., 2010). Hence, the intent of this study is to identify the dynamics contributing to a positive attitude and intention to use a mobile payment service. Attitudes of consumers towards mobile payment services are assessed through perceived security, perceived compatibility, perceived usefulness, perceived ease of use, and subjective norms. This study empirically tests the significance of newly suggested TAM extensions (subjective norm and perceived security) and provides a complete and tested measurement instrument as a basis for future research. In addition, it may be helpful for managers in advancing and improving their current capability to gain greater acceptance by customers.

This paper is organized into six sections. The next section discusses the literature related to consumer behavior towards mobile payment services and the hypotheses of the study. Methodology, including the sampling, data collection techniques, and measurement methods, is discussed in Section 3. Research findings are then presented in the results section, which is followed by implications, and recommendations.

\section{THEORETICAL BACKGROUND}

In the literature on information technology and information science, many models have explained the usage of innovation. Among them, the technology acceptance model (TAM) suggested by Davis in 1989 has gained the greatest 


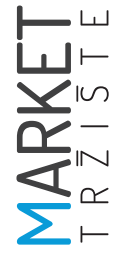

popularity. Also, the theory of reasoned action (TRA) and the theory of planned behavior (TPB) have been widely used as a research framework to assess the individual's adoption behavior in information technology (Ajzen, 1991; Ajzen \& Fishbein, 1980). TRA is designed to predict human behavior by suggesting that the behavior of a person is influenced by behavioral intentions and subjective norm. Intentions capture motivational factors and, as such, reflect the amount of effort people are willing to exert for the intended behavior. TRA was one of the earliest models focused on predicting intentions. TRA comprises two components: attitude towards the performance of a particular act, which is a function of perceived consequences, and subjective norm, which is a function of the significance of the members of reference groups and motivation to act according to their opinions.

An extension of TRA is the theory of planned behavior (TPB), proposed by Ajzen (1991). TPB added the concept of perceived behavioral control to TRA as a third predictor of intention. By suggesting that behavior is under the sole control of intentions, TRA restricts itself to volitional behaviors, such that behaviors requiring skills, resources, or opportunities not freely available are either considered to be outside the domain of TRA's application or would have poor predictability under it (Fishbein, 1993). TPB, on the other hand, can predict non-volitional behaviors by using perceptions of control over performance (perceived behavioral control) as an additional predictor. Aside from psychological studies, TPB has been applied and tested in many fields, including medicine, education, sociology, business, entrepreneurship, and sports. In the light of marketing research, this theory has been supported by empirical studies predominantly related to consumer decision-making (Pavlou \& Fygenson, 2006; Hansen, Jensen \& Solgaard, 2004; Taylor \& Todd, 1995). These studies showed a high degree of accuracy in predicting intentions to perform a specific behavior (Beck \& Ajzen, 1991).
The underlying assumption of the model is that most human behavior is the result of an individual's intention to perform a specific behavior. Furthermore, the intention is under the direct influence of three factors, also known as antecedents of intention: personal attitudes, subjective norms, and perceived behavioral control (Ajzen, 1991).

Personal attitudes are based on the beliefs that an individual possesses about a specific object coupled with attributes attached to that object. Three main dimensions of attitude include (1) a cognitive component, which relates to opinions and beliefs about the object of the attitude, (2) an emotional component, which consists of feelings associated with the object of the attitude, and (3) a behavioral component, which represents willingness to undertake actions in relation to the object of attitude (Voon, Ngui \& Agrawal, 2011). Attributes can be marked as positive or negative, creating a perception of the behavior as desirable or undesirable (Ham, Jeger \& Frajman Ivković, 2015).

Subjective norms reflect the perception of social pressure coming from relevant individuals and directed toward a person to behave in a certain manner weighted by the importance that person attaches to each of those relevant individuals. The selected groups of relevant individuals vary as the type of behavior changes (e.g. intentions to perform behaviors related to one's personal life will probably be under the influence of family members and their beliefs, while the intention to engage in a work-related behavior will more likely be shaped by the beliefs of one's co-workers). Furthermore, subjective norms tend to have a stronger influence on intentions when analyzed within a context of collectivist countries, as opposed to individualist countries (Siu \& Lo, 2013).

Finally, the third antecedent is known as perceived behavioral control. It comprises two facets. The first one, internal control, incorporates the personal judgment of individuals about the sufficiency of their knowledge, skills, and abili- 
ties to engage in a given behavior. The second one, external control, relates to the extent to which individuals perceive that external factors such as time availability and the cooperation of colleagues may hinder or facilitate their behavior (Ajzen, 2002)

Yang, Lu, Gupta, Cao and Zhang (2012) posit that TRA and TPB explain how subjective norms and attitude determine individuals' intentions to adopt any innovation or technology. As an extension of TRA and TPB, Davis (1989) proposed the technology acceptance model (TAM). In other words, TAM is grounded in TRA and TPB. TAM replaces the variables of attitude and behavioral control with technology acceptance methods (Bagozzi, 2007). TAM examines the mediating role of perceived usefulness and perceived ease of use and the relationships between external variables and the probability of information system adoption. The importance of TAM is based on the reliability of the measurement instrument (Pavlou, 2003), and it helps to explain usage intentions (Venkatesh, 1999).

This theory is applied extensively in different studies, such as those on the usage of wireless LAN (Yoon \& Kim, 2007), the acceptance of Internet-based finance (Lee, 2009), and attitudes towards self-service explanations (Dabholkar \& Bagozzi, 2002). TAM can also be used to foresee consumers' attitudes in various settings, as it is useful in explaining consumers' intentions. Hence, we used TAM and extended it with the addition of some other models that are significant to mobile payment facilities acceptance on the basis of prior research.

\subsection{Hypothesis development}

Following the principle of Venkatesh and Davis (2000), we assumed our hypothesis development element(s) with the help of TAM and by adding some extra theories to the original one; that is, we considered intention to use as the main variable. TAM theory explains that the intention of the consumer towards the adoption of a new technology is basically determined by an individual's approach towards the equip- ment (Davis, 1989; Davis, Bagozzi \& Warshaw, 1989), which acts as an intermediary for the impact on other variables. Attitude is defined as the amount of positivity or negativity of an individual towards the technology (Schierz et al., 2010). Allport (1935) defined attitude as a mental and neural state of readiness developed through experience, which exerts a dynamic or directive influence on an individual's response. Attitude is a belief that an individual has gained as a result of adopting a specific behavior (Ajzen \& Fishbein, 1980). According to TRA, the more positive attitude towards the behavior, the greater the intention to adopt a specific behavior. This theory also states that the behavior of an individual is motivated by attitude. TPB theory also explains that intention is a function of attitude (Shih \& Fang, 2004). In previous studies, a positive relationship has been found between attitude and intention to use (Yang \& Yoo, 2004; Schierz et al., 2010). The same structure is adopted in this study; thus, we hypothesize that: (H1)

Attitude towards using mobile payment services has a significant and positive relationship with the intention to use mobile payment services.

Perceived usefulness is the probability of enhancing job performance through the use of a particular system (Davis, 1989). Robey (1979) confirmed that there is a high correlation between perceived usefulness and the actual use of any system. Perceived usefulness in the adoption of mobile services explains how much consumers feel these services to be integrated in their daily life activities (Kleijnen, Wetzels \& De Ruyter, 2004). According to the diffusion theory of Rogers (1995), a consumer's willingness to accept an innovation exists only if it provides unique benefits. This could be the main reason for the slow diffusion of some mobile applications; that is, they fail in communicating the unique advantages to their potential users. The TAM theory posits that perceived usefulness has a direct effect on attitude towards usage (Suh \& Han, 2003). Prior studies have also confirmed that there is a significant relationship between perceived usefulness and adoption of any tech- 


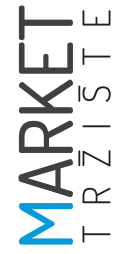

nology (Yang, 2004; O'Cass \& Fenech, 2003; Karahanna, Straub \& Chervany, 1999; Taylor \& Todd, 1995; Guriting \& Ndubisi, 2006; Ramayah \& Suki, 2006). Shanmugam, Savarimuthu and Wen (2014) also confirm a positive and significant relationship between perceived usefulness and attitude. In the framework of TAM, perceived usefulness is considered a predictor for attitude. Hence, it can be hypothesized that: (H2) Perceived usefulness of mobile payment services has a significant and positive relationship with attitude towards using mobile payment services.

According to Davis (1989), perceived ease of use is the degree to which a person believes the use of a particular system to be free of effort. Perceived ease of use is an important driver towards the acceptance of mobile applications (Venkatesh, 2000). However, there is a need to provide benefits which fulfill the ease-of-use criterion. A simple and easy payment process with clear symbol and function keys can create the ease-of-use factor in the mind of a consumer (Pagani \& Schipani, 2004); therefore, we can fit ease of use in our consumer acceptance model. When it comes to non-users, opinion about ease of use can be one of the factors to influence them to accept the use of mobile payment services (Venkatesh \& Davis, 1996). According to the literature discussed above, it can be hypothesized that: (H3) Perceived ease of use of mobile payment services has a significant and positive relationship with attitude towards using mobile payment services.

Innovation in the payment system has gained more importance in consumer research for its potential to generally create risk for customers (Lim, 2003; Mitchell, 1999; Cho, 2004). In automated services, safety risk has been found to be a serious concern for users (Lwin, Wirtz \& Williams, 2007). This risk exists because they haven't had any previous experience with mobile payment methods (Bauer, Reichardt, Barnes \& Neumann, 2005). Secondly, as compared to physical products, services are considered both more problematic to assess and risky (Ge- fen, Karahanna \& Straub, 2003; Mitchell, 1999). While making mobile payments, consumers have concerns about privacy, loss of individual data, and the transaction itself (Bauer, Reichardt \& Schüle, 2005). Trust has a significant effect on acceptance, and according to Egger (2001), trust, reliability, security, and reputation are all factors that influence consumers to accept this type of payment. According to a prior study of Cho (2004), we hypothesize a positive linkage between security (high perceived security) and attitude. Therefore, the fourth hypothesis is formulated as follows: (H4) Perceived security of mobile payment services has a positive relationship with attitude towards using mobile payment services.

Rogers (1962) defines compatibility as the degree to which an innovation is perceived as being consistent with an individual's values, past experiences, and needs. Perceived compatibility is used in the TAM model as an additional factor for mobile payment services (Schierz et al., 2010). Tornatzky and Klein (1982) found that perceived compatibility is a significant factor for customer approval. Rogers (1995) connected compatibility with consumers' needs, past experiences, lifestyles, values, and purchasing habits. If an innovation is consistent with consumers' needs, lifestyle, and values, it will have a better chance to be accepted by consumers. Therefore, perceived compatibility seems to be a useful extension in TAM. Existing research also reflects the positive effect of perceived compatibility on attitude towards technology (Hardgrave, Davis \& Riemenschneider, 2003). Therefore, it can be hypothesized that: (H5) Perceived compatibility of mobile payment services has a positive relationship with attitude towards using mobile payment services.

Subjective norm is defined as perceived social pressure to perform or not to perform a certain behavior (Ajzen, 1991). It is determined by perceived societal pressure with respect to enthusiasm to fulfill various people's expectations. This pressure can be exerted by friends, family, or a person who belongs to one's social group 
(Püschel, Mazzon \& Hernandez, 2010). In acceptance of technological innovations, social context should not be neglected (Schierz et al., 2010). Societal acceptance of technology usage will bring positivity while making decisions (Webster \& Trevino, 1995). Bass's (1969) research of the process from invention to acceptance is significantly influenced by the stresses of the collective organism. Subjective norm has been discussed by Nysveen and others (2005) in a mobile Internet application context and was found to have positive significant impact on attitude. Similarly, Pederson (2005) stated that subjective norm is an important factor in building up attitudes and the intention to use mobile commerce. According to the above-mentioned literature, it can be stated that: (H6) Subjective norm has a posi- tive relationship with attitude towards using mobile payment services.

The hypothesized model for the current study is presented in Figure 1.

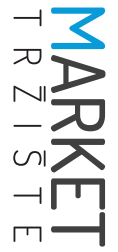

\section{RESEARCH METHODOLOGY}

\subsection{Sampling procedure}

This study investigated consumer attitude towards the implementation of mobile payment services. For this reason, the users of the mobile applications in Karachi, Pakistan were selected as respondents for this study using convenience based sampling. Online Google forms and hard copies of the questionnaire were used

FIGURE 1: Research model

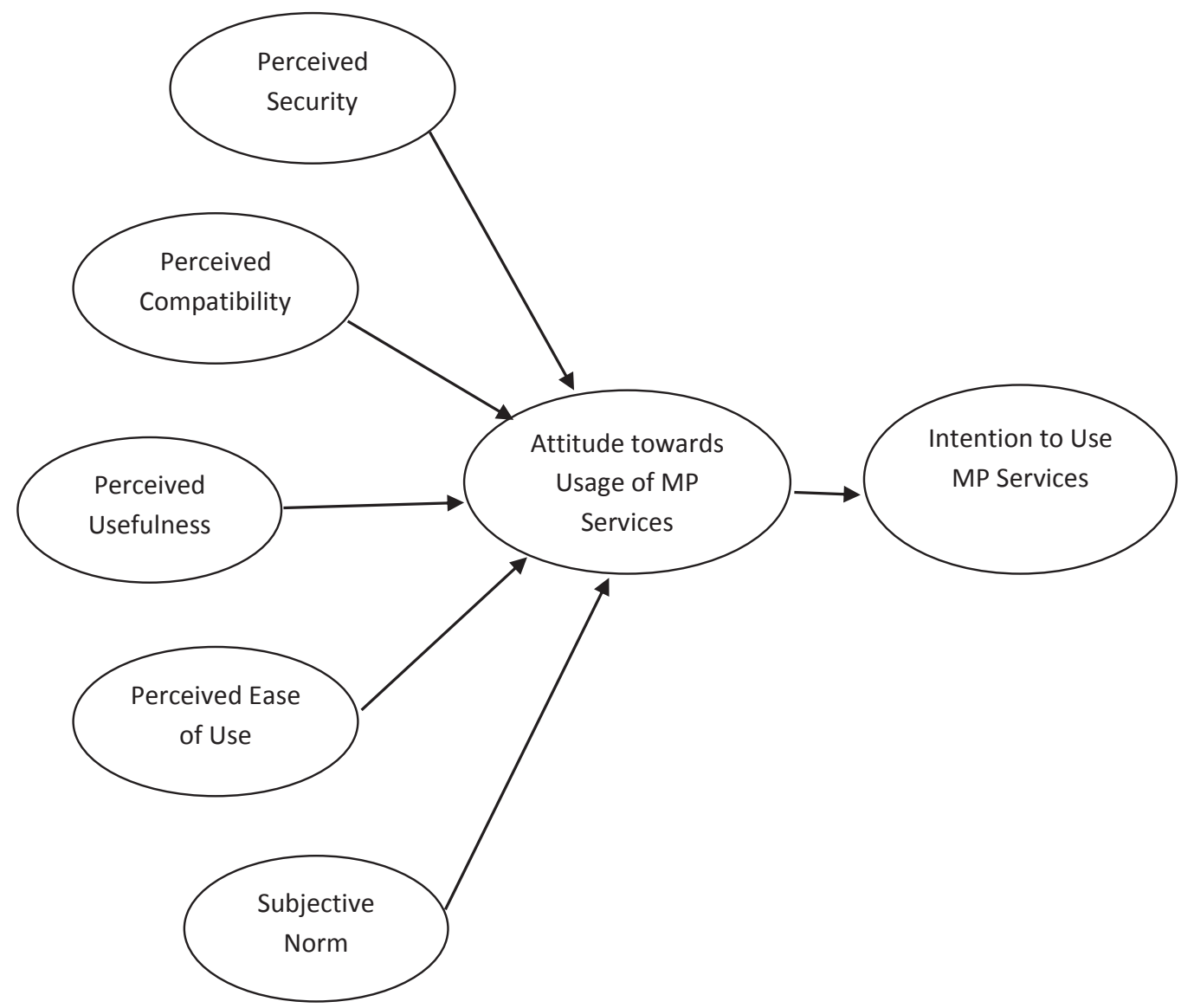


to collect data from the respondents. In total, 415 responses were gathered. During the data screening process for outliers (observations that are distinctly different from other observations), 80 cases were deleted, resulting in 335 usable responses for the analysis. Table 1 shows the demographic profile of the respondents, with $45.5 \%$ males and $55.4 \%$ females. Some $40.2 \%$ of the respondents were graduates, followed by post-graduates with $34.2 \%$, while $38.4 \%$ of the respondents lie in the age bracket of 18 to 25 .

TABLE 1: Demographic profile of respondents

\begin{tabular}{|l|c|c|}
\hline & Frequency & \% \\
\hline Gender & & \\
\hline Male & 153 & 45.5 \\
\hline Female & 182 & 54.5 \\
\hline Age & & \\
\hline $18-25$ & 129 & 38.4 \\
\hline $26-35$ & 78 & 23.2 \\
\hline $36-45$ & 83 & 24.7 \\
\hline 45 or above & 45 & 13.4 \\
\hline Education level & & \\
\hline Postgraduate & 115 & 34.2 \\
\hline Graduate & 135 & 40.2 \\
\hline Undergraduate & 51 & 15.2 \\
\hline Below undergraduate & 34 & 10.1 \\
\hline
\end{tabular}

\subsection{Variables and measurement}

A highly structured adapted questionnaire was used to collect the responses, with a Likert scale ranging from 1 to 5 , where 1 stands for "strongly disagree", 2 for "disagree", 3 represents neutral, 4 stands for "agree", and 5 for "strongly agree". The questionnaire was adapted from Schierz and others (2010), and some items were added based on the following previous research.

The Attitude Scale was designed based on the research of Oh, Ahn and Kim (2003), Van Der Heijden (2003), Yang and Yoo (2004), and Schierz and others (2010). Four items were used in this study to measure attitude towards the adoption of mobile service payments.
The Intention-to-Use Scale has four items, which were defined based on the research of Davis, (1989), Gefen and others (2003), Venkatesh and Davis (2000), and Schierz and others (2010).

The Perceived Usefulness Scale consists of four items which were designed based on the research of Bhattacherjee (2001), Devaraj, Fan and Kohli (2002), Van Der Heijdan (2003), and Schierz and others (2010).

Perceived Ease of Use was measured with the four-item scale designed based on the items used by Bhattacherjee (2001), Davis and others (1989), Taylor and Todd (1995), Venkatesh and Davis (2000), and Schierz and others (2010).

Perceived Security was measured with a fouritem scale based on the items used by Luarn and Lin (2005), Parasuraman, Zeithaml and Malhotra (2005), and Schierz and others (2010).

The Perceived Compatibility Scale has three items designed based on the research of Moore and Benbasat (1991), Plouffe, Hulland and Vandenbosch (2001), and Schierz and others (2010).

Subjective Norm was measured via three items, based on the work of Taylor and Todd (1995), Venkatesh and Davis (2000), and Schierz and others (2010).

EFA was used for the formation of the constructs by using SPSS 22.0. According to Raza and Hanif (2013), factor analysis contracts a large set of data into a small set and brings into line the correlated items. CFA was then performed to obtain the results of model fitness, and SEM was applied using Amos 22.0 to examine the significance of the latent variable.

\section{RESEARCH RESULTS}

Table 2 depicts the values of exploratory factor analysis (EFA), which was performed in order to get the constructs aligned. For each construct, coefficient alpha, composite reliability (CR), and the average variance extracted (AVE) were analyzed. The value of coefficient alpha should be above 0.7 (Nunnally, 1978), composite reliability 
TABLE 2: EFA and reliability

\begin{tabular}{|c|c|c|}
\hline Items: & Adopted source & $\begin{array}{l}\text { Factor } \\
\text { loading }\end{array}$ \\
\hline \multicolumn{3}{|l|}{ ATTITUDE: (Cronbach's = 0.862) } \\
\hline Using mobile payment services is a good idea. & \multirow{4}{*}{$\begin{array}{l}\text { Oh et al., (2003), van der Heijden } \\
\text { (2003), Yang and Yoo (2004), } \\
\text { Schierz et al., (2010) }\end{array}$} & 0.814 \\
\hline Using mobile services payment is wise. & & 0.722 \\
\hline Using mobile payment services is beneficial. & & 0.844 \\
\hline Using mobile payment services is interesting. & & 0.632 \\
\hline \multicolumn{3}{|l|}{ INTENTION : (Cronbach's = 0.919) } \\
\hline Given the opportunity, I will use mobile payment services. & \multirow{4}{*}{$\begin{array}{l}\text { Davis (1989), Gefen et al., (2003), } \\
\text { Venkatesh and Davis (2000), } \\
\text { Schierz et al., (2010) }\end{array}$} & 0.686 \\
\hline I am likely to use mobile payment services in the near future. & & 0.804 \\
\hline I am willing to use mobile payment services in the near future. & & 0.768 \\
\hline I intend to use mobile payment services if the opportunity arises. & & 0.754 \\
\hline \multicolumn{3}{|l|}{ PERCEIVED USEFULNESS: (Cronbach's = 0.789) } \\
\hline Mobile payment services are a useful mode of payment & \multirow{4}{*}{$\begin{array}{l}\text { Bhattacherjee (2001), Devaraj et } \\
\text { al. (2002), van der Heijden (2003), } \\
\text { Schierz et al., (2010) }\end{array}$} & 0.516 \\
\hline $\begin{array}{l}\text { Using mobile payment services makes the handling of payments } \\
\text { easier. }\end{array}$ & & 0.658 \\
\hline Mobile payment services allow for faster usage of mobile applications. & & 0.713 \\
\hline $\begin{array}{l}\text { By using mobile payment services, my choices as a consumer are } \\
\text { improved. }\end{array}$ & & 0.595 \\
\hline \multicolumn{3}{|l|}{ PERCEIVED EASE OF USE: (Cronbach's = 0.913) } \\
\hline It is easy to become skillful at using mobile payment services. & \multirow{4}{*}{$\begin{array}{l}\text { Bhattacherjee (2001), Davis et al., } \\
\text { (1989), Taylor and Todd (1995), } \\
\text { Venkatesh and Davis (2000), } \\
\text { Schierz et al., (2010) }\end{array}$} & 0.78 \\
\hline $\begin{array}{l}\text { The interaction with mobile payment services is clear and } \\
\text { understandable. }\end{array}$ & & 0.809 \\
\hline $\begin{array}{l}\text { It is easy to perform the steps required to use mobile payment } \\
\text { services. }\end{array}$ & & 0.844 \\
\hline It is easy to interact with mobile payment services. & & 0.797 \\
\hline \multicolumn{3}{|l|}{ PERCEIVED SECURITY: (Cronbach's = 0.920) } \\
\hline The risk of an unauthorized third party overseeing the payment is low. & \multirow{4}{*}{$\begin{array}{l}\text { Luarn and Lin (2005), } \\
\text { Parasuraman et al. (2005), Schierz } \\
\text { et al., (2010) }\end{array}$} & 0.863 \\
\hline $\begin{array}{l}\text { The risk of abuse of usage (e.g. names of business partners, payment } \\
\text { amount) is low. }\end{array}$ & & 0.918 \\
\hline $\begin{array}{l}\text { The risk of abuse of billing information (e.g. credit card number, bank } \\
\text { account data) is low. }\end{array}$ & & 0.886 \\
\hline $\begin{array}{l}\text { I would find mobile payment services secure when conducting my } \\
\text { payment transactions. }\end{array}$ & & 0.797 \\
\hline \multicolumn{3}{|l|}{ PERCEIVED COMPATIBLITY: (Cronbach's = 0.881) } \\
\hline Using mobile payment services fits well with my lifestyle. & \multirow{3}{*}{$\begin{array}{l}\text { Moore and Benbasat (1991), } \\
\text { Plouffe et al. (2001), Schierz et } \\
\text { al., (2010) }\end{array}$} & 0.723 \\
\hline $\begin{array}{l}\text { Using mobile payment services fits well with the way I like to purchase } \\
\text { products and services. }\end{array}$ & & 0.772 \\
\hline $\begin{array}{l}\text { I would appreciate using mobile payment services instead of } \\
\text { alternatives modes of payment (e.g. credit card and cash) }\end{array}$ & & 0.644 \\
\hline \multicolumn{3}{|l|}{ SUBJECTIVE NORM: (Cronbach's = 0.928) } \\
\hline $\begin{array}{l}\text { People who are important to me would recommend using mobile } \\
\text { payment services. }\end{array}$ & \multirow{3}{*}{$\begin{array}{l}\text { Taylor and Todd (1995), } \\
\text { Venkatesh and Davis (2000), } \\
\text { Schierz et al., (2010) }\end{array}$} & 0.847 \\
\hline $\begin{array}{l}\text { People who are important to me would find using mobile payment } \\
\text { services to be beneficial. }\end{array}$ & & 0.848 \\
\hline $\begin{array}{l}\text { People who are important to me would consider using mobile } \\
\text { payment services to be a good idea }\end{array}$ & & 0.894 \\
\hline
\end{tabular}

Using mobile payment services is beneficial.

Using mobile payment services is interesting.

I intend to use mobile payment services if the opportunity arises.

Using mobile payment services makes the handling of payments

veyment services a low for faster usage of mobile applications. improved.

PERCEIVED EASE OF USE: (Cronbach's $=\mathbf{0 . 9 1 3}$ )

It is easy to become skillful at using mobile payment services. understandable. services. Venkatesh and Davis (2000), Schierz et al., (2010)

molie payment services. 
should be more than 0.7, and average variance extracted should be above 0.5 (Bagozzi \& Yi, 1988). The results of AVE indicate that there is no problem in the discriminant validity of factors, as the results of AVE measure of each factor is larger than the squared correlation of that factor's measure with all the measures of other factors.

Table 3 shows the values of CFA.

TABLE 3: Confirmatory factor analysis

\begin{tabular}{|c|c|c|c|c|}
\hline Constructs & Items & $\begin{array}{c}\text { Standardized } \\
\text { loadings }\end{array}$ & CR & AVE \\
\hline \multirow{2}{*}{$\begin{array}{l}\text { Perceived } \\
\text { Compatibility }\end{array}$} & PC1 & 0.89 & \multirow[t]{2}{*}{0.84} & \multirow[t]{2}{*}{0.724} \\
\hline & PC2 & 0.81 & & \\
\hline \multirow{2}{*}{$\begin{array}{l}\text { Perceived } \\
\text { Security }\end{array}$} & PS1 & 0.64 & \multirow[t]{2}{*}{0.858} & \multirow[t]{2}{*}{0.675} \\
\hline & PS4 & 0.98 & & \\
\hline \multirow{2}{*}{$\begin{array}{l}\text { Perceived } \\
\text { Usefulness }\end{array}$} & PU2 & 0.73 & \multirow[t]{2}{*}{0.71} & \multirow[t]{3}{*}{0.533} \\
\hline & PU1 & 0.73 & & \\
\hline \multirow{3}{*}{$\begin{array}{l}\text { Perceived } \\
\text { Ease of Use }\end{array}$} & PE2 & 0.96 & \multirow[t]{3}{*}{0.937} & \\
\hline & PE3 & 0.81 & & \multirow[t]{2}{*}{0.833} \\
\hline & PE4 & 0.96 & & \\
\hline \multirow{3}{*}{$\begin{array}{l}\text { Subjective } \\
\text { Norm }\end{array}$} & SN1 & 0.8 & \multirow[t]{3}{*}{0.793} & \multirow[t]{3}{*}{0.793} \\
\hline & SN2 & 1 & & \\
\hline & SN3 & 0.86 & & \\
\hline \multirow[t]{3}{*}{ Attitude } & AT1 & 0.61 & \multirow[t]{3}{*}{0.70} & \multirow[t]{3}{*}{0.438} \\
\hline & AT2 & 0.65 & & \\
\hline & AT4 & 0.72 & & \\
\hline \multirow{3}{*}{$\begin{array}{l}\text { Intention to } \\
\text { Use }\end{array}$} & 11 & 0.92 & \multirow[t]{3}{*}{0.887} & \multirow[t]{3}{*}{0.725} \\
\hline & 12 & 0.81 & & \\
\hline & 13 & 0.82 & & \\
\hline
\end{tabular}

Model fitness was confirmed by three types of fitness measures: absolute, incremental, and parsimony fitness measures. The values of the fitness measures satisfied the threshold values and confirmed their adequacy for further estimation. According to Aslam, Batool and Haq (2016), the value of $\times 2 / d f$ should be between 1 and 3, and the result obtained was 2.102. Other values necessary to report are as follows: $\mathrm{CFI}=$
$0.922(>0.90), \mathrm{NFI}=0.905(>0.90), \mathrm{IFI}=0.923(>$ $0.90), \mathrm{PCFI}=0.675(>0.50)$, and PNFI $=0.662(>$ 0.50). The values of these thresholds were confirmed based on Bagozzi and Yi (1988). The RMSEA value is: 0.062. RMSEA should be less than 0.08 (Browne \& Cudeck, 1993); preferably less than 0.05 (Stieger, 1990).

The results indicate that perceived usefulness has a remarkable (positive) impact on attitude towards mobile payment services $(\beta=0.60, p$ $\leq 0.01$ ), thus supporting the second hypothesis $(H 2)$. Perceived compatibility $(\beta=0.19, p \leq$ 0.05 ) as well as subjective norm ( $\beta=0.17, p \leq$ $0.01)$ also have a positive and significant relation with consumer attitude towards mobile payment services, which supports $\mathrm{H} 5$ and $\mathrm{H} 6$. However, perceived security and perceived ease of use have insignificant impact $(\beta=0.08, p \geq$ 0.1 and $\beta=0.04, p \geq 0.1$, respectively); therefore, $\mathrm{H} 4$ and $\mathrm{H} 3$ are not supported. The results also indicate that attitude towards the use of mobile payment services has a significant and positive impact on the intention to use mobile payment services ( $\beta=0.91, p \leq 0.1$ ), thus supporting the first hypothesis $(\mathrm{H} 1)$. $\mathrm{R}^{2}$ between the independent constructs and attitude towards mobile payment services was found to be 0.83 , while that between attitude and intention to adopt mobile payment services was 0.84 . The overall results are provided in Table 4.

TABLE 4: Path analysis

\begin{tabular}{|l|c|c|c|c|l|}
\hline Path & Estimates & S.E. & C.R. & P & Results \\
\hline PC $\rightarrow$ AT & 0.19 & 0.042 & 2.2 & 0.028 & Supported \\
\hline PS $\rightarrow$ AT & 0.08 & 0.033 & 1.604 & 0.109 & $\begin{array}{l}\text { Not } \\
\text { supported }\end{array}$ \\
\hline PU $\rightarrow$ AT & 0.60 & 0.09 & 5.205 & $* * *$ & Supported \\
\hline PE $\rightarrow$ AT & 0.04 & 0.031 & 0.621 & 0.535 & $\begin{array}{l}\text { Not } \\
\text { supported }\end{array}$ \\
\hline SN $\rightarrow$ AT & 0.17 & 0.027 & 3.516 & $* * *$ & Supported \\
\hline AT $\rightarrow \mid$ & 0.91 & 0.121 & 12.19 & $* * *$ & Supported \\
\hline
\end{tabular}


Table 5 presents the correlation analysis data.

TABLE 5: Correlations analysis

\begin{tabular}{|c|c|c|c|c|c|c|c|}
\hline & AT & I & PU & PE & PS & PC & SN \\
\hline AT & 1 & & & & & & \\
\hline I & $.632^{* *}$ & 1 & & & & & \\
\hline PU & $.583^{* *}$ & $.608^{* *}$ & 1 & & & & \\
\hline PE & $.468^{* *}$ & $.541^{* *}$ & $.512^{* *}$ & 1 & & & \\
\hline PS & $.291^{* *}$ & $.440^{* *}$ & $.287^{* *}$ & $.430^{* *}$ & 1 & & \\
\hline PC & $.526^{* *}$ & $.590^{* *}$ & $.516^{* *}$ & $.530^{* *}$ & $.443^{* *}$ & 1 & \\
\hline SN & $.449^{* *}$ & $.442^{* *}$ & $.370^{* *}$ & $.348^{* *}$ & $.300^{* *}$ & $.503^{* *}$ & 1 \\
\hline Mean & 4.0773 & 3.8994 & 4.186 & 3.9171 & 3.4819 & 3.7717 & 3.7665 \\
\hline S.D. & 0.64986 & 0.75651 & 0.5857 & 0.7389 & 0.9028 & 0.89345 & 0.85589 \\
\hline
\end{tabular}

\section{DISCUSSION AND IMPLICATIONS}

This study identified the key factors of the acceptance of mobile payment services by using a research model based on TAM. Perceived ease of use, perceived usefulness, subjective norm, perceived security, and perceived compatibility were used to examine each consumer's attitude towards mobile payment services and their intention to adopt mobile payment services. In addition, the goal of this research was to understand the consumers' preferences and to identify their requirements for the use of mobile payment services. The measurement instrument used for the study was an adapted questionnaire, based on a 5-point Likert scale. The results indicate that perceived usefulness, perceived compatibility, and subjective norm are the most influential variables in determining consumer attitude towards mobile payment services, while ease of use and perceived security were found to be insignificant. Hence, we can say that perceived ease of use does not affect consumer attitude towards mobile payment services. This result is congruent with the results of research on mobile banking done by Shanmugam and others (2014), who also found perceived ease of use to have no impact on consumer attitudes towards mobile banking.
Marketers should, therefore, communicate the usefulness of the mobile payment technology to consumers as a way of helping improve the consumer attitude towards mobile payment services. As far as the ease of use is concerned, it seems that consumers presume it to be unimportant, so it is no longer a significant variable in the decision-making process for adopting the use of this technology. However, the providers of these services should by all means strive to keep them user friendly and simple to use. In a marketing sense, mobile payment technology can no longer be a source of competitive advantage; instead, it is a prerequisite of competitive parity. The same can probably be assumed for the perceived security variable, as well. However, it most likely depends on the level of confidence consumers have in legal institutions to protect them in case of malpractice. Therefore, it would be useful in the future research to further investigate the dimensions of perceived security and the presumed differences in different countries.

The determined influence of perceived compatibility and perceived usefulness points to the conclusion that it would be beneficial for the marketers of mobile payment services to educate consumers about how this technology can complement their busy lifestyle. There is a prevailing overall trend of constant perceived 
lack of time, and Internet-based technologies, especially mobile payment services, are the right answer to the challenges of modern life for a growing number of consumers. Also, the influence of subjective norm points to the benefits of informing consumers about the growing number of mobile payment service users while also identifying opinion leaders in order to benefit from their influence on consumers.

\section{LIMITATIONS AND RECOMMENDATIONS FOR FUTURE RESEARCH}

This study is restricted to a sample in Karachi, Pakistan. In order to get more holistic results, the study could be done nationwide; it could be fruitful to assess the attitudes of consumers towards mobile payment services in other countries, as well. A cross-cultural study would also be beneficial for getting more generalizable results of consumer behavior towards mobile payment services. Another point worth mentioning is that the sample used represents mostly young and educated people, and they are typical users of technology. That kind of sample could have important implications for the study results. The reason is that the study examined consumer conduct with respect to the implementation of mobile payment services, and users who are able to use the mobile applications were selected as respondents. Future research could also strive to investigate the attitudes of mobile applications non-users to discover the specific influences on their behavior.

As mentioned earlier, in future research, it would be beneficial to further investigate the dimensions of perceived security because it probably depends on the level of trust consumers have in legal institutions. Furthermore, the subjective norm variable could be upgraded by capturing not only what the members of the reference group think (social norms) but also what they actually do (descriptive norms). Some previous research (Ham et al., 2015; Rivis \& Sheeran, 2003) confirms the usefulness of incorporating both social and descriptive norms.

And finally, other factors such as individual mobility or the degree to which an individual is involved with mobile technology can also be added to assess the adoption of mobile payment services.

\section{References}

1. Ajzen, I. (2002). Perceived behavioral control, Self-Efficacy, locus of control, and the theory of planned Behavior. Journal of applied social psychology, 32(4), 665-683.

2. Ajzen, I., \& Fishbein, M. (1980). Understanding attitudes and predicting social behaviour. Boston, MA: Prentice-Hall.

3. Ajzen, I., (1991). The theory of planned behaviour. Organizational behavior and human decision processes, 50(2), 179-211.

4. Allport, G. W. (1935). Attitudes: A Handbook of Social Psychology. Worcester: Clark University Press.

5. Arif, I., Aslam, W., \& Ali, M. (2016). Students' dependence on smartphones and its effect on purchasing behavior. South Asian Journal of Global Business Research, 5(2), 285-302.

6. Aslam, W., Batool, M., \& Haq, Z. U. (2016). Attitudes and Behavior of the Mobile Phones Users towards SMS Advertising: A Study in an Emerging Economy. Journal of Management Sciences, 3(1), 63-80.

7. Bagozzi, R. P. (2007). The legacy of the technology acceptance model and a proposal for a paradigm shift. Journal of the association for information systems, 8(4), 244-254.

8. Bagozzi, R. P., \& Yi, Y. (1988). On the evaluation of structural equation models. Journal of the academy of marketing science, 16(1), 74-94. 
9. Bakker, E. (2016). The mobile payments report: Market forecasts, consumer trends, and the barriers and benefits that will influence adoption. Available at: http://www.businessinsider.com/the-mobilepayments-report-market-forecasts-consumer-trends-and-the-barriers-and-benefits-that-will-influence-adoption-2016-5 (Retrieved December 19 ${ }^{\text {th }}, 2016$ )

10. Bass, F. M. (1969). A new product growth for model consumer durables. Management science, 15(5), 215-227.

11. Bauer, H. H., Reichardt, T., \& Schüle, A. (2005). User requirements for location based services. Proceedings of the IADIS International Conference in e-Commerce, Porto, 211-218.

12. Bauer, H. H., Reichardt, T., Barnes, S. J., \& Neumann, M. M. (2005). Driving consumer acceptance of mobile marketing: A theoretical framework and empirical study. Journal of electronic commerce research, 6(3), 181-192.

13. Beck, L., \& Ajzen, I. (1991). Predicting dishonest actions using the theory of planned behaviour. Journal of research in personality, 25(3), 285-301.

14. Bhattacherjee, A. (2001). Understanding information systems continuance: an expectation-confirmation model. MIS quarterly, 19, 351-370.

15. Browne, M. W., \& Cudeck, R. (1993). Alternative ways of assessing model fit. In: K. A. Bollen \& J. S. Long (Eds.). Testing structural equation models (pp. 136-162). Newsbury Park, CA: Sage.

16. Cho, J. (2004). Likelihood to abort an online transaction: influences from cognitive evaluations, attitudes, and behavioral variables. Information \& Management, 41(7), 827-838.

17. Dabholkar, P. A., \& Bagozzi, R. P. (2002). An attitudinal model of technology-based self-service: moderating effects of consumer traits and situational factors. Journal of the academy of marketing science, 30(3), 184-201.

18. Davis, F. D. (1989). Perceived usefulness, perceived ease of use, and user acceptance of information technology. MIS quarterly, 13, 319-340.

19. Davis, F. D., Bagozzi, R. P., \& Warshaw, P. R. (1989). User acceptance of computer technology: a comparison of two theoretical models. Management science, 35(8), 982-1003.

20. Devaraj, S., Fan, M., \& Kohli, R. (2002). Antecedents of B2C channel satisfaction and preference: validating e-commerce metrics. Information systems research, 13(3), 316-333.

21. Egger, F. N. (2001). Affective design of e-commerce user interfaces: How to maximise perceived trustworthiness. Proceeding of International Conference Affective Human Factors Design, 317-324.

22. Fishbein, M. (1993). Introduction. In: D. J., Terry, C. Gallois \& M. McCamish (Eds.). The theory of reasoned action: its application to AIDS-preventive behaviour. Oxford: Pergamon Press.

23. Gefen, D., Karahanna, E., \& Straub, D. W. (2003). Trust and TAM in online shopping: an integrated model. MIS quarterly, 27(1), 51-90.

24. Guriting, P., \& Ndubisi, N. O. (2006). Borneo online banking: evaluating customer perceptions and behavioural intention. Management research news, 29(1/2), 6-15.

25. Ham, M., Jeger, M., \& Frajman Ivković, A. (2015). The role of subjective norms in forming the intention to purchase green food. Economic Research-Ekonomska Istraživanja, 28(1), 738-748.

26. Hansen, T., Jensen, J. M., \& Solgaard, H. S. (2004). Predicting online grocery buying intention: a comparison of the theory of reasoned action and the theory of planned behaviour. International Journal of Information Management, 24(6), 539-550.

27. Hardgrave, B. C., Davis, F. D., \& Riemenschneider, C. K. (2003). Investigating determinants of software developers' intentions to follow methodologies. Journal of Management Information Systems, 20(1), 123-151.

28. Hwang, R. J., Shiau, S. H., \& Jan, D. F. (2007). A new mobile payment scheme for roaming services. Electronic Commerce Research and Applications, 6(2), 184-191. 
29. Ibrahim, S. (2016). Mobile Money Revolution: The Next Big Thing in Pakistan. Available at: https:// www.phoneworld.com.pk/mobile-money-revolution-next-big-thing-pakistan/ (Accessed October $\left.14^{\text {th }}, 2016\right)$.

30. Karahanna, E., Straub, D. W., \& Chervany, N. L. (1999). Information technology adoption across time: a cross-sectional comparison of pre-adoption and post-adoption beliefs. MIS quarterly, 23(2), 183-213.

31. Kleijnen, M., Wetzels, M., \& De Ruyter, K. (2004). Consumer acceptance of wireless finance. Journal of financial services marketing, 8(3), 206-217.

32. Lee, M. C. (2009). Factors influencing the adoption of internet banking: An integration of TAM and TPB with perceived risk and perceived benefit. Electronic Commerce Research and Applications, 8(3), 130-141.

33. Lim, N. (2003). Consumers' perceived risk: sources versus consequences. Electronic Commerce Research and Applications, 2(3), 216-228.

34. Luarn, P., \& Lin, H. H. (2005). Toward an understanding of the behavioral intention to use mobile banking. Computers in human behavior, 21(6), 873-891.

35. Lwin, M., Wirtz, J., \& Williams, J. D. (2007). Consumer online privacy concerns and responses: a power-responsibility equilibrium perspective. Journal of the Academy of Marketing Science, 35(4), 572-585.

36. Mitchell, V. W. (1999). Consumer perceived risk: conceptualisations and models. European Journal of marketing, 33(1/2), 163-195.

37. Moore, G. C., \& Benbasat, I. (1991). Development of an instrument to measure the perceptions of adopting an information technology innovation. Information systems research, 2(3), 192-222.

38. Nunnally, J. C. (1978). Psychometric Theory. New York, NY: McGraw-Hill.

39. Nysveen, H., Pedersen, P. E., \& Thorbjørnsen, H. (2005). Intentions to use mobile services: Antecedents and cross-service comparisons. Journal of the academy of marketing science, 33(3), 330346.

40. O'Cass, A., \& Fenech, T. (2003). Web retailing adoption: exploring the nature of internet users Web retailing behaviour. Journal of Retailing and Consumer services, 10(2), 81-94.

41. Oh, S., Ahn, J., \& Kim, B. (2003). Adoption of broadband Internet in Korea: the role of experience in building attitudes. Journal of Information Technology, 18(4), 267-280.

42. Pagani, M., \& Schipani, D. (2008). Motivations and barriers to the adoption of $3 G$ mobile multimedia services: an end-user perspective in the Italian market. In: S. R. Rahman (Ed.). Multimedia Technologies: Concepts, Methodologies, Tools, and Applications (pp. 182-192). Boston, MA: IGI Global.

43. Parasuraman, A., Zeithaml, V. A., \& Malhotra, A. (2005). ES-QUAL a multiple-item scale for assessing electronic service quality. Journal of service research, 7(3), 213-233.

44. Pavlou, P. A. (2003). Consumer acceptance of electronic commerce: Integrating trust and risk with the technology acceptance model. International journal of electronic commerce, 7(3), 101134.

45. Pavlou, P. A., \& Fygenson, M. (2006). Understanding and predicting electronic commerce adoption: An extension of the theory of planned behaviour. MIS quarterly, 30(1), 115-143.

46. Pedersen, P. E. (2005). Adoption of mobile Internet services: An exploratory study of mobile commerce early adopters. Journal of organizational computing and electronic commerce, 15(3), 203-222.

47. Plouffe, C. R., Hulland, J. S., \& Vandenbosch, M. (2001). Research report: richness versus parsimony in modeling technology adoption decisions - understanding merchant adoption of a smart card-based payment system. Information systems research, 12(2), 208-222. 
48. Püschel, J., Mazzon, J. A., \& Hernandez, J. M. C. (2010). Mobile banking: Proposition of an integrated adoption intention framework. International Journal of Bank Marketing, 28(5), 389-409.

49. Ramayah, T., \& Suki, N. M. (2006). Intention to use mobile PC among MBA students: implications for technology integration in the learning curriculum. UNITAR e-Journal, 1(2), 1-10.

50. Rampton, J. (2016). The evolution of the mobile payment. Available at: https://techcrunch. com/2016/06/17/the-evolution-of-the-mobile-payment (Retrieved December $8^{\text {th }}, 2016$ ).

51. Raza, S. A., \& Hanif, N. (2013). Factors affecting internet banking adoption among internal and external customers: a case of Pakistan. International Journal of Electronic Finance, 7(1), 82-96.

52. Rivis, A., \& Sheeran, P. (2003). Descriptive norms as an additional predictor in the theory of planned behaviour: A meta-analysis. Current Psychology, 22(3), 218-233.

53. Robey, D. (1979). User attitudes and management information system use. Academy of Management Journal, 22(3), 527-538.

54. Rogers, E. M. (1995). Diffusion of innovations. New York, NY: The Free Press.

55. Rogers, E. M. (1962). Diffusion of Innovations. New York, NY: The Free Press.

56. Schierz, P. G., Schilke, O., \& Wirtz, B. W. (2010). Understanding consumer acceptance of mobile payment services: An empirical analysis. Electronic commerce research and applications, 9(3), 209-216.

57. Shanmugam, A., Savarimuthu, M. T., \& Wen, T. C. (2014). Factors affecting Malaysian behavioral intention to use mobile banking with mediating effects of attitude. Academic Research International, 5(2), 236-253.

58. Shih, Y. Y., \& Fang, K. (2004). The use of a decomposed theory of planned behavior to study Internet banking in Taiwan. Internet Research, 14(3), 213-223.

59. Siu, W. S., \& Lo, E. S. C. (2013). Cultural contingency in the cognitive model of entrepreneurial intention. Entrepreneurship Theory and Practice, 37(2), 147-173.

60. Smith, A., Anderson, J., \& Rainie, L. (2016). The Future of Money in a Mobile Age. Available at: http://www.pewinternet.org/2012/04/17/the-future-of-money-in-a-mobile-age/ (Retrieved December $\left.18^{\text {th }}, 2016\right)$.

61. Steiger, J. H. (1990). Structural model evaluation and modification: An interval estimation approach. Multivariate Behavioural Research, 25, 173-180.

62. Suh, B., \& Han, I. (2003). Effect of trust on customer acceptance of Internet banking. Electronic Commerce research and applications, 1(3), 247-263.

63. Taylor, S., \& Todd, P. A. (1995). Understanding information technology usage: A test of competing models. Information systems research, 6(2), 144-176.

64. Tornatzky, L. G., \& Klein, K. J. (1982). Innovation characteristics and innovation adoption-implementation: A meta-analysis of findings. IEEE Transactions on engineering management, 29(1), 28-45.

65. Van der Heijden, H. (2003). Factors influencing the usage of websites: the case of a generic portal in The Netherlands. Information \& management, 40(6), 541-549.

66. Venkatesh, V. (1999). Creation of favorable user perceptions: Exploring the role of intrinsic motivation. MIS quarterly, 23(2), 239-260.

67. Venkatesh, V. (2000). Determinants of perceived ease of use: Integrating control, intrinsic motivation, and emotion into the technology acceptance model. Information systems research, 11(4), 342-365.

68. Venkatesh, V., \& Davis, F. D. (1996). A model of the antecedents of perceived ease of use: Development and test. Decision sciences, 27(3), 451-481.

69. Venkatesh, V., \& Davis, F. D. (2000). A theoretical extension of the technology acceptance model: Four longitudinal field studies. Management science, 46(2), 186-204.

70. Voon, J. P., Ngui, K. S., \& Agrawal, A. (2011). Determinants of Willingness to Purchase Organic Food: An Exploratory Study Using Structural Equation Modeling. International Food and Agribusiness Management Review, 14(2), 103-120. 
71. Webster, J., \& Trevino, L. K. (1995). Rational and social theories as complementary explanations of communication media choices: Two policy-capturing studies. Academy of Management Journal, 38(6), 1544-1572.

72. Yang, H. D., \& Yoo, Y. (2004). It's all about attitude: revisiting the technology acceptance model. Decision Support Systems, 38(1), 19-31.

73. Yang, K. C. (2004). A comparison of attitudes towards Internet advertising among lifestyle segments in Taiwan. Journal of Marketing Communications, 10(3), 195-212.

74. Yang, S., Lu, Y., Gupta, S., Cao, Y., \& Zhang, R. (2012). Mobile payment services adoption across time: An empirical study of the effects of behavioral beliefs, social influences, and personal traits. Computers in Human Behavior, 28(1), 129-142.

75. Yoon, C., \& Kim, S. (2007). Convenience and TAM in a ubiquitous computing environment: The case of wireless LAN. Electronic Commerce Research and Applications, 6(1), 102-112. 